\title{
Structure of the bottom water flow in the Vema Channel based on the measurements from the R/V Akademik Sergey Vavilov
}

\author{
E. G. Morozov ${ }^{1}$, D. I. Frey ${ }^{1}$, V. A. Krechik ${ }^{1}$, M. V. Kapustina ${ }^{1}$, and M. N. Pisareva ${ }^{1}$
}

Received 12 April 2021; accepted 3 May 2021; published 20 May 2021.

The bottom waters in the Atlantic Ocean originate from the Weddell Sea. These waters of Antarctic origin flow from the Argentine Basin to the Brazil Basin along three pathways: through the Vema and Hunter channels and over the Santos Plateau. The Vema Channel is a conduit for the coldest and densest Antarctic waters to the north. It is a narrow passage between two terraces with a minimum width of $16 \mathrm{~km}$. The propagation of bottom waters in the deep-water Vema Channel occurs as a well-mixed jet. The coldest part of the flow is displaced to the eastern slope of the deep-water channel due to the influence of the bottom Ekman friction. The second core of the flow is observed in the upper part of the channel over its western slope. This jet was also found in the continuation of the AABW flow at the exit from the Vema Channel. We analyze data over the section across the Vema Channel collected in several years of research from the R/V Akademik Sergey Vavilov. KEYWORDS: Antarctic Bottom Water; Vema Channel; abyssal flows; R/V Akademik Sergey Vavilov.

Citation: Morozov, E. G., D. I. Frey, V. A. Krechik, M. V. Kapustina, and M. N. Pisareva (2021), Structure of the bottom water flow in the Vema Channel based on the measurements from the R/V Akademik Sergey Vavilov,

Russ. J. Earth. Sci., 21, ES3003, doi:10.2205/2021ES000769.

\section{Introduction}

Antarctic Bottom Water (AABW) occupies the lowest ocean layer in the deep basins of the Atlantic. This water originates from the Weddell Sea; however, thermohaline properties of AABW in different deep basins differ. An increase in the temperature and salinity along the pathways of bottom water propagation is caused by mixing of AABW with warmer and more saline North Atlantic Deep Water in the overlying layers. This mixing strongly intensifies when the current of bottom water overflows underwater ridges through abyssal channels. The ocean topography plays the most important

\footnotetext{
${ }^{1}$ Shirshov Institute of Oceanology RAS, Moscow, Russia
}

Copyright 2021 by the Geophysical Center RAS. http://rjes.wdcb.ru/doi/2021ES000769-res.html role in the formation of thermohaline structure in the deep basins. We used the results of hydrographic measurements from the R/V Akademik Sergey Vavilov for this study.

The bottom waters of Antarctic origin flow from the Argentine Basin to the Brazil Basin along three pathways: through the Vema Channel, through the Hunter Channel, and over the Santos Plateau. Among them, the Vema Channel is the main pathway for the flow of AABW [Morozov et al., 2020a. The depths of the Vema Channel exceed $4600 \mathrm{~m}$, while the background depths of the Santos Plateau and Hunter Channel are approximately 4000-4200 m. The Vema Channel is a narrow passage between two terraces with a minimum width slightly greater than $15 \mathrm{~km}$. Investigations in these channels provide evidence that the Vema Channel plays a dominating role in the transport of Antarctic waters compared to the other passages. 
The Mid-Atlantic Ridge divides the Atlantic Ocean into two parts and causes significant differences between the deep and bottom waters of the West and East Atlantic. These waters originate in the polar regions; generally, colder and denser Antarctic waters occupy the bottom layer while warmer and lighter North Atlantic waters are located above them [Frey et al., 2019a; Johnson, 2008]. The bottom water density difference in the basins of the South and North Atlantic is caused by the relatively shallow underwater ridges between Greenland, Iceland, the Faeroe Islands, and Scotland, which prevent the free propagation of cold bottom Arctic waters to the south. Despite the fact that North Atlantic Deep Water (NADW) overlies the ocean bottom in some parts of the North Atlantic [Mantyla and Reid, 1983 almost all bottom layers of the Atlantic Ocean are occupied by AABW [Johnson, 2008]. The classical definition of the boundary between these water masses is the isotherm of potential temperature $\theta=2.0^{\circ} \mathrm{C}$.

The formation of bottom waters occurs at a few locations on the Antarctic shelf of the Weddell Sea [Orsi et al., 1999]. After sinking to the abyssal depths, these waters mix with the Southern Ocean waters and form a northward flow of AABW in the South Atlantic [Lumpkin and Speer, 2007]. The properties of AABW change during its northward propagation. The flow patterns of AABW strongly depend on the local topography. In particular, the coldest part of AABW propagates to the equator in the Southwest Atlantic because of the topographic obstacles in its southeastern part [Morozov et al., 2008, 2010.

\section{Data and Methods}

This research is based on the CTD/LADCP profiling, which has been performed many times in the Vema Channel since the 1970s. These measurements were carried out from the Russian research vessels in 2002, 2003, 2004, 2005, 2006, 2009, 2017, 2018, and 2020. Most of the data were collected from the R/V Akademik Sergey Vavilov. Sections across the Vema Channel were also made by our colleagues from Germany and US starting from 1991. Measurements of temperature, electrical conductivity, and depth were performed at each hydrographic station using an SBE-19 plus CTD profiler, and an SBE 33 on-board device (Carousel Deck Unit). Current velocities were measured by a Lowered Acoustic Doppler Current Profiler (LADCP, RDI WH Sentinel, $300 \mathrm{kHz}$ ) mounted together with the CTD on the SBE 32 rosette (Carousel Water Sampler). The measurements stopped at a distance of 3-7 $\mathrm{m}$ above the bottom double checked by an altimeter (model Benthos PSA-196) and a pinger (Benthos Co) [Frey et al., 2017a, Morozov et al., 2020b.

\section{Temperature and Salinity Measurements in the Channel}

Let us first consider the sections across the channel occupied in different years since 1991. All sections were made in the narrow part of the channel close to the Vema Sill at $31^{\circ} 12^{\prime}$ S. Distributions of temperature and salinity over sections across the channel near the Vema Sill along $31^{\circ} 12^{\prime} \mathrm{S}$ or $31^{\circ} 14^{\prime} \mathrm{S}$ in 2003, 2017, and 2018 from the R/V Akademik Sergey Vavilov are shown in Figure 1 Figure 2, Contour lines of density are also shown in the figures. Measurements made in these expeditions and many other expeditions showed that the cold core of Antarctic Bottom Water is usually displaced to the eastern slope of the channel. The core is a jet of well-mixed water. The thickness of the core is approximately $150-200 \mathrm{~m}$.

The width of the cold core is approximately one fourth of the channel. The upper boundary of the core migrates in time between 4300 and $4400 \mathrm{~m}$. High location of the boundary results in a sharp thermocline over the core. The bottom Ekman friction induces secondary helical circulation relative to the general current, which displaces the coldwater core to the right (to the east if the current is directed to the north) in the Southern Hemisphere [Johnson et al., 1976]. In the Southern Hemisphere, the Ekman friction is directed to the right of the flow, which agrees with the modeling results of [Frey et al., 2017b, 2019b, Jungclaus and Vanicek, 1999, Morozov et al., 2020b.

Sections of temperature and salinity across the Vema Channel are usually occupied along $31^{\circ} 12^{\prime} \mathrm{S}$. This is the standard section occupied 14 times already. Many times, this section was extended to the west beyond the western slope of the channel. In addition to the strong flow of bottom wa- 
ter along the bed of the channel, another jet is found over the western slope of the channel approximately 300-400 $\mathrm{m}$ shallower than the deepest one [Morozov et al., 2018, 2020a, Tarakanov et al., 2020]. The cold core of this flow is displaced to the west relative to the center of the channel. This phenomenon was observed in 1991, 1992, 2002, 2006, 2009, 2017, 2018, and 2020. In these years, the section was extended to the west unlike other years when the measurements were confined only to the deepest part of the channel. We suppose that this upper core over the western wall exists always. This jet exists due to the displacement of the flow by the Coriolis force.

Fourteen sections across the channel in different years show that the structure details of the flow change every time as the researchers make measurements. However, the general feature associated with the displacement of the jet to the eastern slope at the bottom is almost the same. The CTD measurements in different years show changes in the jet structure. The cold core is mixed well in the vertical direction. The horizontal stratification exists always. The changes in stratification, location of the jet, and its structure are clearly seen in Figure 1 Figure 2.

When the cold jet is strongly displaced to the eastern slope and elevated, a strong temperature gradient is observed at the upper boundary of the slope. This happens because the lower isotherms are elevated by the core of the flow, while the upper remain at their previous depths.

\section{Velocity Measurements in the Channel}

Since 2005, the CTD measurements in the Vema Channel were accompanied with velocity measurements using a Lowered Acoustic Doppler Current Profiler (LADCP). These measurements allowed us to analyze the spatial structure of the flow in the channel. The structure of the current field changes in time. In 2005, the minimum measured velocities were $29 \mathrm{~cm} \mathrm{~s}^{-1}$, while in 2009 they were as high as $35 \mathrm{~cm} \mathrm{~s}^{-1}$. The maximum velocities equal to $55 \mathrm{~cm} \mathrm{~s}^{-1}$ were measured in 2017. In 2018, the maximum velocities did not exceed $30 \mathrm{~cm} \mathrm{~s}^{-1}$. The greatest velocities were measured by instruments on a mooring, they were as high as $60 \mathrm{~cm} \mathrm{~s}^{-1}$. The maximum velocities are usually recorded in the middle of the channel approximately $100 \mathrm{~m}$ above the bottom. Sections of meridional velocity across the channel in 2017-2018 are shown in Figure 3.

Transport of Antarctic Bottom Water in the Vema Channel was estimated from the LADCP data. It is interesting to compare the transport of Antarctic Bottom Water with potential temperatures $\theta<2.0^{\circ} \mathrm{C}$. The transports were calculated between the walls of the channel. If the section did not reach the walls the data were extrapolated.

In addition, a wide range of Antarctic Bottom Water transport in the Vema Channel is found in the literature. All estimates range between 2 and $4.5 \mathrm{~Sv}$ [Hogg et al., 1999, McDonagh et al., 2002, Speer and Zenk, 1993, Wienders et al., 2000, Zenk and Hogg, 1996. Our estimates based on LADCP data between the walls of the channel show a range of transport below $\theta=2.0^{\circ} \mathrm{C}$ potential temperature within 1.6-3.7 Sv, which is closer to the lower boundary of the interval in publications and close to the range in [Hogg et al., 1999. McDonagh et al., 2002 .

\section{Conclusions}

We investigated a strong flow of Antarctic Bottom Water through the Vema Channel from the Argentine to the Brazil Basin on the basis of measurements over the standard section at $31^{\circ} 12^{\prime} \mathrm{S}$ at the Vema Sill crossing the channel. The mean transport of Antarctic Bottom Water (layer below $\theta=2.0^{\circ} \mathrm{C}$ isotherm) through the Vema Channel is estimated at $1.6-3.7 \mathrm{~Sv}$. The greatest velocities reach $60 \mathrm{~cm} \mathrm{~s}^{-1}$. The propagation of bottom waters in the deep-water Vema Channel occurs as a well-mixed jet in a layer approximately $150 \mathrm{~m}$ thick. Owing to the Ekman friction, the coldest core of the flow in the Vema Channel is usually displaced to the eastern slope of the channel. Another jet of AABW flow was found over the western wall of the channel. The maximum velocities are usually recorded in the middle of the channel approximately $100 \mathrm{~m}$ above the bottom.

Acknowledgments. The work was carried out within the State Task of the Russian Federation 0128-20190008; the data analysis was supported by the Russian Science Foundation (grant 21-77-20004). 


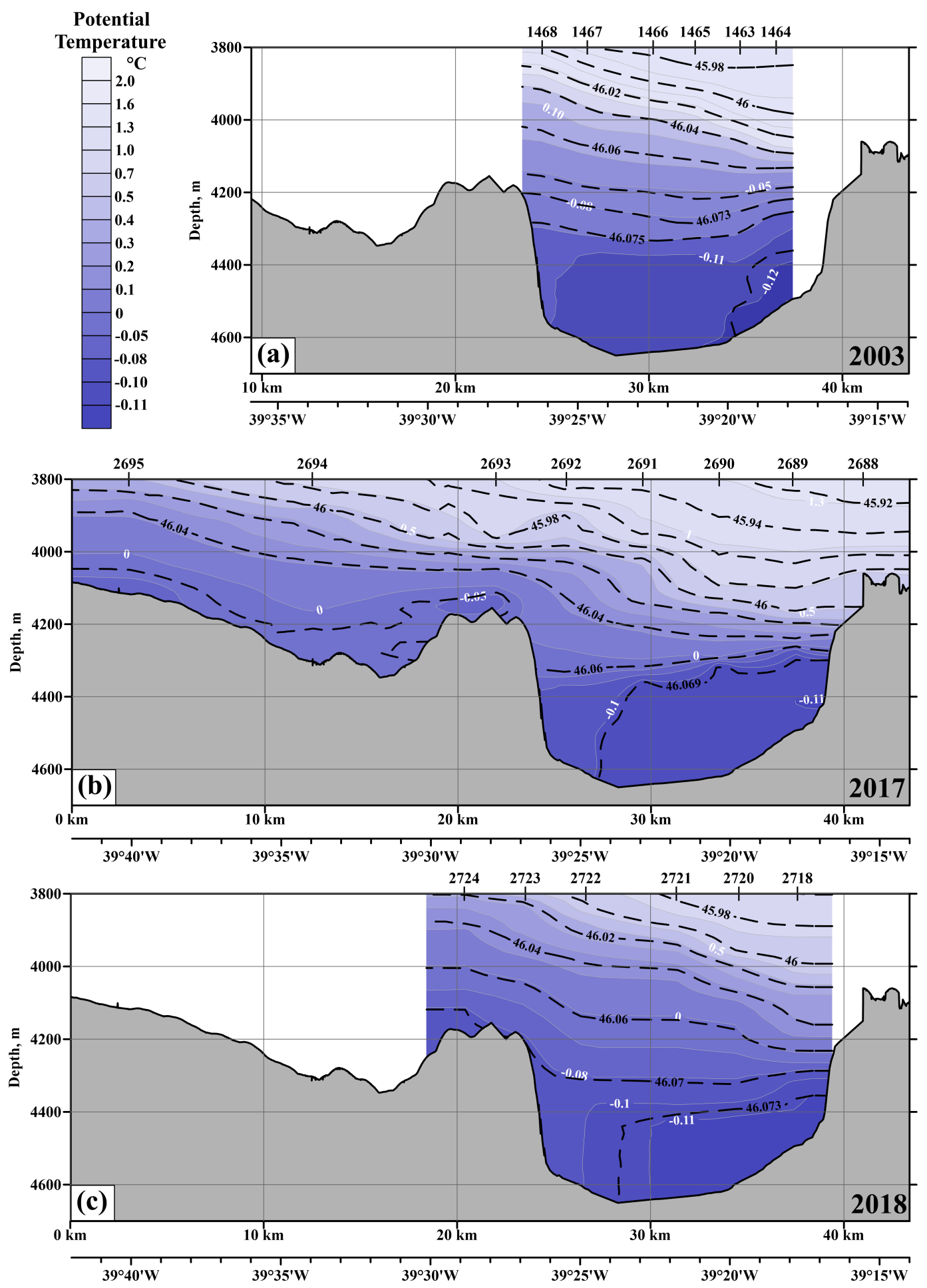

Figure 1. Distributions of potential temperature $\left({ }^{\circ} \mathrm{C}\right)$ over the zonal sections across the channel at the Vema Sill $\left(31^{\circ} 12^{\prime}-31^{\circ} 14^{\prime}\right.$ S) in 2003 (a), 2017 (b), and 2018 (c). Contour lines of density are shown with thick dash-dotted lines. 

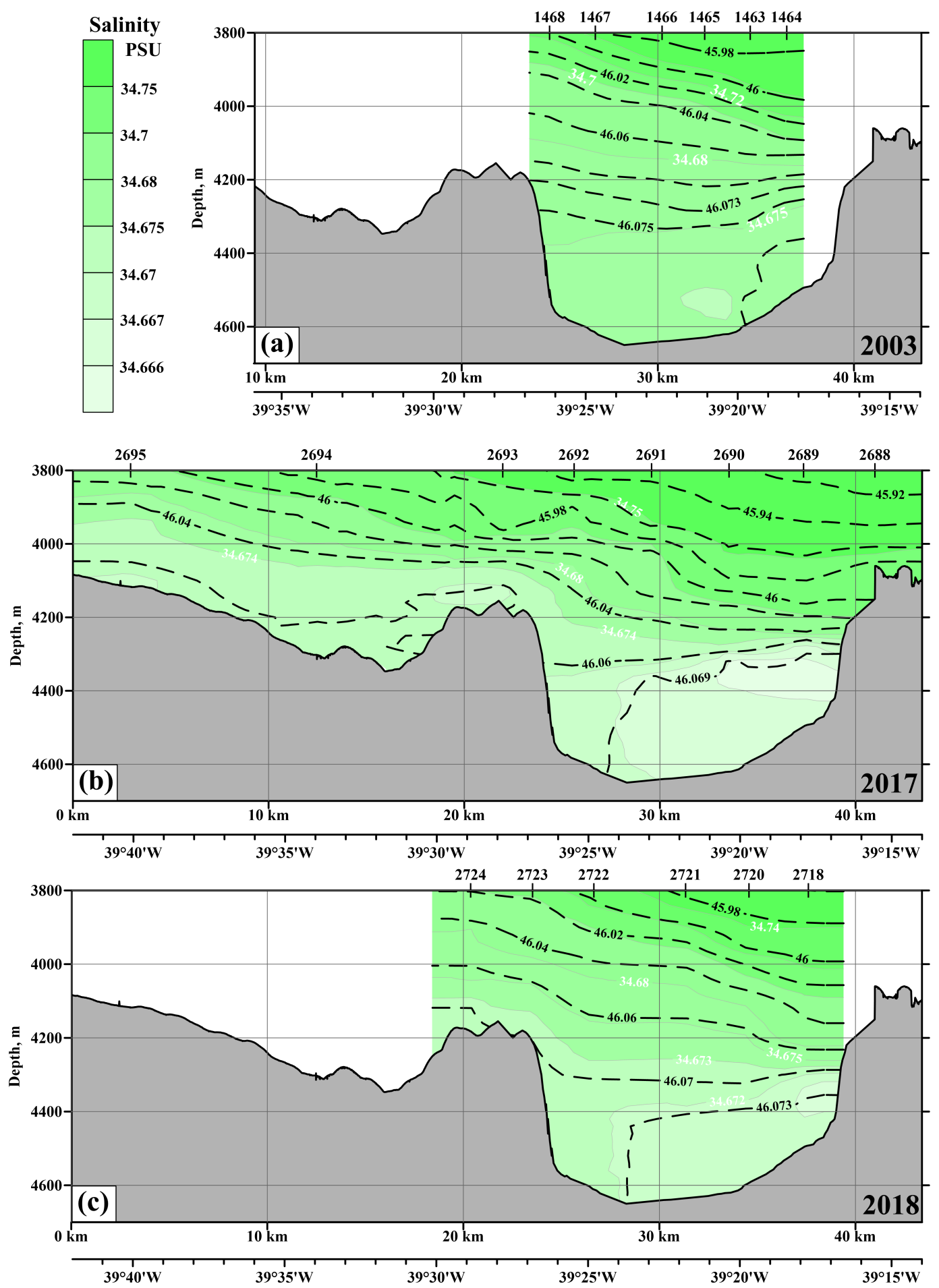

Figure 2. Distributions of salinity (PSU over the zonal sections across the channel at the Vema Sill $\left(31^{\circ} 12^{\prime}-31^{\circ} 14^{\prime} \mathrm{S}\right)$ in 2003 (a), 2017 (b), and 2018 (c). Contour lines of density are shown with thick dash-dotted lines. 

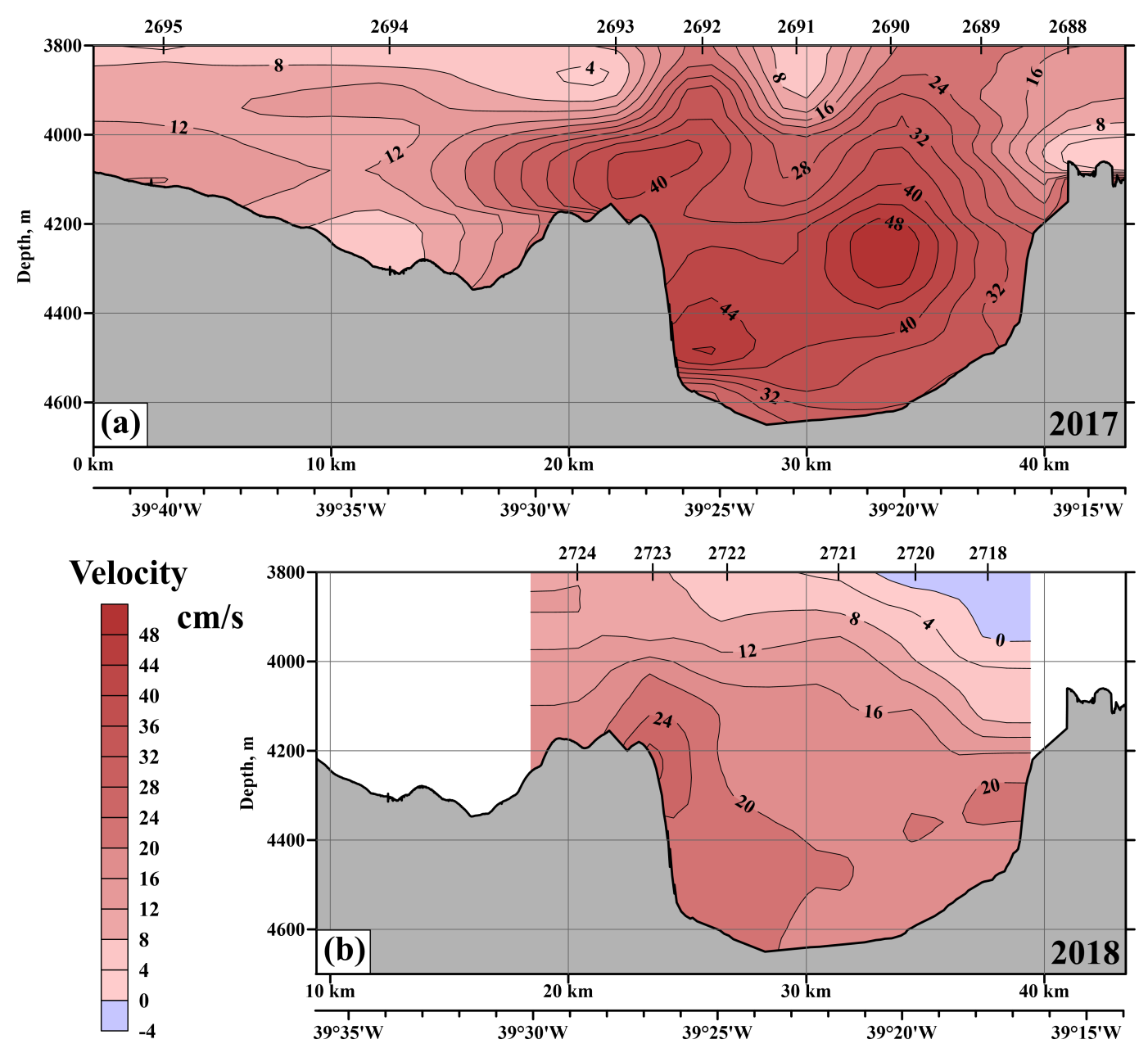

Figure 3. Distributions of meridional velocity $(\mathrm{cm} / \mathrm{s})$ over the zonal sections across the channel at the Vema Sill $\left(31^{\circ} 12^{\prime}-31^{\circ} 14^{\prime}\right.$ S) 2017 (a), and 2018 (b) based on the LADCP data. In 2003, there were no ADCP measurements.

\section{References}

Frey, D. I., A. N. Novigatsky, et al. (2017a), Water structure and currents in the Bear Island Trough in July-August, Russian Journal of Earth Sciences, 17, ES3003, Crossref

Frey, D. I., V. V. Fomin, et al. (2017b), New model and field data on estimates of Antarctic Bottom Water flow through the deep Vema Channel, Doklady Earth Sciences, 474, No. 1, 561-564, Crossref

Frey, D. I., E. G. Morozov, et al. (2019a), Thermohaline structure of Antarctic Bottom Water in the abyssal basins of the South Atlantic, Russian Journal of Earth Sciences, 19, ES5005, Crossref

Frey, D. I., E. G. Morozov, et al. (2019b), Regional modeling of Antarctic Bottom Water flows in the key passages of the Atlantic, Journal of Geophysical Research: Oceans, 124, No. 11, 8414, Crossref
Hogg, N., G. Siedler, W. Zenk (1999), Circulation and variability at the southern boundary of the Brazil Basin, J. Phys. Oceanogr., 29, 145-157, Crossref

Johnson, D. A., S. E. McDowell, et al. (1976), Abyssal topography, nephelometry, currents, and benthic boundary layer structure in the Vema Channel, J. Geophys. Res. Oceans, 81, 5771-5786, Crossref Johnson, G. C. (2008), Quantifying Antarctic Bottom Water and North Atlantic Deep Water volumes, J. Geophys. Res. Oceans, 113, C05027, Crossref Jungclaus, J., M. Vanicek (1999), Frictionally modified flow in a deep ocean channel: Application to the Vema Channel, J. Geophys. Res. Oceans, 104, No. C9, 21,123-21,136, Crossref

Lumpkin, R., K. Speer (2007), Global ocean meridional overturning, J. Phys. Oceanogr., 37, 25502562, Crossref

Mantyla, A. W., J. L. Reid (1983), Abyssal characteristics of the World Ocean waters, Deep-Sea Res. I, 30, No. 8, 805-833, Crossref 
McDonagh, E. L., M. Arhan, K. J. Heywood (2002), On the circulation of bottom water in the region of the Vema, Channel Deep-Sea Res. I, 49, 1119-1139, Crossref

Morozov, E. G., A. N. Demidov, R. Yu. Tarakanov (2008), Transport of Antarctic Waters in the deep channels of the Atlantic Ocean, Doklady Earth Sciences, 423, No. 8, 1286-1289, Crossref

Morozov, E. G., A. N. Demidov, et al. (2010), Abyssal Channels in the Atlantic Ocean: Water Structure and Flows, 266 pp. Springer, Dordrecht. Crossref

Morozov, E. G., R. Yu. Tarakanov, et al. (2018), Currents and water structure north of the Vema Channel, Russian Journal of Earth Sciences, 18, ES5006, Crossref

Morozov, E. G., D. I. Frey, R. Y. Tarakanov (2020a), Flow of Antarctic Bottom Water from the Vema Channel, Geoscience Letters, 7 , Crossref

Morozov, E. G., D. I. Frey, et al. (2020b), The extreme northern jet of the Antarctic Circumpolar Current, Russian Journal of Earth Sciences, 20, ES5004, Crossref

Orsi, A. H., G. C. Johnsson, J. L. Bullister (1999), Circulation, mixing, and production of Antarctic Bot- tom Water, Progress in Oceanogr., 43, 55-109, Crossref

Speer, K. G., W. Zenk (1993), The flow of Antarctic Bottom water into the Brazil Basin, J. Phys. Oceanogr., 23, 2667-2682, Crossref

Tarakanov, R. Y., E. G. Morozov, D. I. Frey (2020), Hydraulic continuation of the abyssal flow from the Vema Channel in the southwestern part of the Brazil Basin, J. Geophys. Res. Oceans, 125, e2020JC016232, Crossref

Wienders, N., M. Arhan, H. Mercier (2000), Circulation at the western boundary of the South and Equatorial Atlantic: Exchanges with the ocean interior, J. Mar. Res., 58, 1007-1039, Crossref

Zenk, W., N. G. Hogg (1996), Warming trend in Antarctic Bottom Water flowing into the Brazil Basin, Deep-Sea Res. I, 43, No. 9, 1461-1473, (in Russian) Crossref

\section{Corresponding author:}

E. G. Morozov, Shirshov Institute of Oceanology, Russian Academy of Sciences, 36 Nakhimovskii prospect, 117997 Moscow, Russia. (egmorozov@mail.ru) 